\title{
SEKOLAH INKLUSI SEBAGAI ARENA KEKERASAN SIMBOLIK
}

\author{
Nanang Martono, Mintarti, Elis Puspitasari, dan Sulyana Dadan \\ Prodi Sosiologi Universitas Jenderal Soedirman Purwokerto \\ E-mail: nanang.martono@unsoed.ac.id,
}

\begin{abstract}
ABSTRAK. Penelitian ini mendeskripsikan kekerasan simbolik yang terjadi di sekolah favorit. Ketika siswa dari keluarga miskin diberi kesempatan bersekolah di sekolah yang mayoritas siswa berasal dari kelas atas, maka siswa dari kelas bawah akan mengenal banyak habitus kelas atas. Di sinilah awal terjadinya kekerasan simbolik di sekolah. Studi ini menggambarkan bagaimana siswa miskin melakukan interaksi sosial di sekolah meskipun memiliki habitus yang berbeda dengan habitus mayoritas siswa di sekolah. Sekolah yang dipilih sebagai lokasi penelitian adalah sekolah yang didominasi siswa kelas atas di Kota Cilacap. Penelitian menggunakan metode kualitatif dengan mewawancarai beberapa siswa miskin di sekolah tersebut. Hasil studi menunjukkan bahwa beberapa siswa merasa minder ketika harus berinteraksi dengan siswa kaya. Mereka sulit mengikuti habitus temannya yang berasal dari kelas atas, misalnya: nonton film di bioskop, jalan-jalan ke mall, dan lainnya. Siswa lain memiliki bersikap masa bodoh dan tidak dekat dengan temannya yang berbeda kelas sosial. Kesimpulan studi menyatakan bahwa sekolah inklusi yang mengakomodasi siswa dari banyak golongan sosial ekonomi merupakan upaya strategis pemerataan kesempatan belajar. Namun di sisi lain, ketika sebuah sekolah didominasi siswa dari kelas atas, maka kondisi ini sebenarnya kurang menguntungkan bagi siswa miskin di sekolah yang tersebut.
\end{abstract}

Kata kunci: kekerasan simbolik; siswa miskin; sekolah; habitus

\section{INCLUSIVE SCHOOL AS THE ARENA OF SYMBOLIC VIOLENCE}

\begin{abstract}
This research describe simbolic violance that occur at favourite school. When students from poor family are given the chance to study at school that majority come from high class, so low class students will know much high class habitus. Here is the begining of simbnolic violence at school.This study describes how the poor students do social interaction at school although they have different habitus with the habit of majority students at school. The choosen school as the research location is the school that dominated high class students in Cilacap. This research uses qualitative method by interviewing some low class students at that school. The study shows that some students are inconfidence when they have to interact with high class students. They find difficulties to follow the habitus of their friends that come from high class, for examples: watching movie at cinema, strolling at mall, and so on. The other students don't care and not closed with their friends from different class. The study conclusion says inclusive school that accomodate the students from many social economic group is an strategic effort of study chance equality. However, on the other side, when a school is dominated high class students, so this condition actually is unprofitable for the poor students at that school.
\end{abstract}

Keywords: symbolic violence; poor student; school; habitus

\section{PENDAHULUAN}

Membuka kesempatan seluas-luasnya kepada semua warga negara untuk mengakses pendidikan berkualitas adalah tugas dan kewajiban negara. Kesempatan ini tidak hanya diberikan untuk golongan tertentu saja, melainkan untuk semua golongan masyarakat. Ini adalah bentuk meritokrasi untuk mewujudkan sistem pendidikan yang demokratis.

Dalam beberapa waktu terakhir biaya pendidikan meningkat secara signifikan. Akibatnya sekolah hanya dapat diakses golongan menengah ke atas saja. Kelompok masyarakat miskin sulit mengakses pendidikan berkualitas. Sekolah kemudian menjadi lembaga eksklusif yang dapat diakses segelintir orang saja. Sekolah mahal selalu menjadi momok yang sangat menakutkan bagi warga miskin dan menjadi bahan diskusi di mana-mana (Martono, 2014).

Untuk menanggapi pandangan miring mengenai sekolah mahal, pemerintah mengeluarkan kebijakan sekolah gratis, terutama untuk jenjang pendidikan dasar dan pendidikan menengah. Pemerintah berharap dengan kebijakan ini warga miskin akan mudah mengenyam pendidikan (Martono, 2014). Pemerintah mengucurkan dana BOS (Bantuan Operasional Sekolah) untuk membantu sekolah-sekolah agar mereka mampu meningkatkan kualitasnya. Harapannya adalah ada kesamaan akses bagi warga miskin ke sekolah-sekolah yang selama ini dianggap hanya milik siswa kaya. Sekolah pun diharapkan mampu menjadi lembaga inklusif yang terbuka untuk semua golongan.

Dalam praktiknya, meskipun sekolah adalah gratis, namun masih ada pengotak-kotakan tempat sekolah untuk si kaya dan si miskin. Ada sebagian sekolah yang mayoritas siswanya berasal dari keluarga kaya, dan sebagian lain diisi siswa dari keluarga miskin. Sekolah gratis ternyata belum mampu menghapus dikotomi sekolah favorit dan sekolah tidak favorit. Sekolah favorit masih didominasi siswa kelas atas, sementara sekolah tidak favorit juga masih didominasi siswa dari kelas bawah. Sekolah gratis ternyata belum mampu mengeliminasi segregasi sosial dalam pendidikan di Indonesia.

Pada proses PPDB (Penerimaan Peserta Didik Baru) tahun 2017, selain menerapkan sistem PPDB 
online, pemerintah melalui Kemendikbud mencoba menerapkan sistem zonasi. Sistem ini mengharuskan siswa memilih dan bersekolah di sekolah terdekat dengan domisilinya tanpa memperhatikan kualitas akademiknya. Dalam jangka panjang, sistem ini bertujuan menghapus dikotomi sekolah favorit dan tidak favorit. Sistem zonasi secara tidak langsung juga memiliki misi lain yaitu memberikan akses yang sama bagi siswa miskin yang selama ini tidak berkesempatan masuk di sekolahsekolah favorit meskipun sekolah tersebut dekat dengan tempat tinggalnya.

Namun, secara sosiologis, pemberian akses yang sama bagi siswa miskin dan kaya dalam satu sekolah bukanlah sebuah solusi yang mampu mengatasi semua masalah ketimpangan sosial dalam pendidikan. Ketika siswa miskin dan siswa kaya bersekolah di sekolah yang sama, ada problem sosiologis yang muncul.

Pertama, berkaitan dengan masalah kemampuan akademik. Sebagaimana dijelaskan sebelumnya, sekolah harus memprioritaskan siswa miskin jika ia memang berada pada zona yang dekat dengan sekolah. Pada tataran ini, siswa miskin dengan kualifikasi akademik tinggi tidak menghadapi masalah yang cukup berarti. Namun, bagi siswa miskin yang memiliki kualitas akademik rendah kemudian mereka harus bersaing dengan siswa kaya yang memiliki kualifikasi akademik tinggi, bagaimana mereka dapat menyamakan prestasinya? Masalah prestasi bukan semata karena ia mendapat materi yang sama, diajar guru yang sama di ruang kelas yang sama. Namun, ada faktor lain yang tidak diperoleh di sekolah dan sulit dimiliki siswa miskin. Misalnya: mengikuti les di lembaga bimbingan belajar serta fasilitas internet 24 jam.

Kedua, secara sosiologis ada hambatan saat berinteraksi yang dialami siswa miskin. Ini dapat ditemukan ketika mereka harus berinteraksi dengan siswa kaya di sekolah. Bourdieu (1973) menjelaskan bahwa siswa miskin dan siswa kaya memiliki "modal" dan habitus yang berbeda. Habitus merupakan budaya, gaya hidup, kebiasaan yang dimiliki sekelompok individu. Habitus setiap individu dan kelompok adalah berbeda, bergantung pada modal yang dimilikinya. Jadi, dengan perbedaan modal tersebut, Bourdieu pesimis siswa miskin akan mampu menyamai prestasi siswa kelas atas karena si miskin tidak mampu menyamai habitus si kaya.

Isu yang menarik dari tesis Bourdieu ini adalah bahwa siswa kaya dan siswa miskin memiliki modal dan habitus yang berbeda. Habitus ini akan berdampak pada proses interaksi yang dilakukan keduanya. Bagaimana mereka berinteraksi dengan habitus yang berbeda? Inilah yang menjadi fokus penelitian ini.

Dalam contoh sehari-hari, hambatan interaksi karena perbedaan habitus ini adalah dalam "bahan percakapan" antara siswa kaya dan siswa miskin. Foucault (Martono, 2014a) menyatakan bahwa wacana (dalam hal ini adalah isi percakapan) adalah berbeda menurut ruang dan waktu. Misalnya: wacana tentang asyiknya tamasya ke luar kota atau keseruan bermain game online hanya dapat dijumpai dalam wacana siswa kaya. Wacana ini tidak berkembang dalam lingkungan siswa miskin. Dengan habitus dan wacana yang berbeda tersebut, mampukah siswa miskin mengikuti atau menyesuaikan diri dengan budaya kelompok mayoritas, yaitu siswa kaya. Ketika mereka bercakap di ruang yang sama, apa yang akan diungkapkan si miskin?

Lebih lanjut, Bourdieu (1973) mengatakan bahwa habitus yang berkembang di sekolah adalah habitus kelas atas saja. Baginya, sekolah sebagai arena pertemuan si kaya dan si miskin ternyata tidak mengakomodasi habitus kelas miskin. Bourdieu menyebut gejala ini sebagai "kekerasan simbolik", ketika kelompok minoritas dipaksa mempelajari dan mengikuti habitus kelas dominan (kelas atas).

Untuk itu, penelitian ini menganalisis bagaimana siswa miskin "menerima" habitus siswa kaya dalam interaksi sosial mereka di sekolah. Apa yang mereka rasakan ketika berinteraksi dengan siswa yang memiliki habitus berbeda tersebut?

\section{Sekolah sebagai ruang inklusif}

Sejatinya, sekolah adalah ruang publik yang dapat diakses semua kelompok masyarakat. Habermas (dalam Hardiman, 2010) menjelaskan bahwa ruang publik merupakan media tempat mengkomunikasikan berbagai informasi dan pandangan hidup seseorang. Ruang publik juga menyangkut ruang yang tidak saja bersifat fisik, akan tetapi juga ruang tempat proses komunikasi dapat berlangsung. Ruang publik yang tidak bersifat fisik ini adalah media massa.

Sekolah sebagai ruang publik menyiratkan makna bahwa siapapun sebenarnya dapat berinteraksi di sana. Sebagai ruang publik, sekolah menjadi tempat bebas tanpa belenggu kekuasaan. Di ruang tersebut, siswa dan guru seharusnya dapat berinteraksi satu sama lain tanpa batasan berarti.

Perkembangan kapitalisme kemudian masuk ke sekolah yang menyebabkan sekolah menjadi ruang eksklusif yang hanya dapat diakses segelitir orang. Para "penikmat" sekolah adalah kelompok bourjuis yang memiliki cukup modal untuk masuk ke sekolah. Kelompok kapitalis menggunakan sekolah sebagai sarana mewujudkan tujuannya: salah satunya menggunakan sekolah sebagai pabrik penghasil tenaga kerja (Bowles \& Gintis, 1978).

Sekolah berubah menjadi sebuah lembaga eksklusif yang tidak bebas kepentingan. Sekolah menjadi tempat melakukan seleksi sosial. Sekolah juga menjadi manifestasi kekuasaan yang bertugas menentukan siapa-siapa saja yang berhak mendapatkan posisi sosial yang lebih baik daripada yang lain. Dalam dunia kerja, 
peran ini mudah dijumpai ketika status pekerjaan tertentu hanya dapat diduduki individu tertentu. Dasar kualifikasi adalah tingkat pendidikan dan keterampilan yang berhasil dimiliki setelah melalui proses pendidikan di sekolah. Status atau tingkat pendidikan yang berhasil diraih individu akan menempatkannya dalam kelompok atau kelas tertentu. Artinya, status pendidikan menjadi dasar untuk menentukan status sosial individu dalam masyarakat. Bourdieu (1973) melihat status pendidikan yang diwujudkan dalam selembar ijasah sebagai sebuah bentuk modal budaya yang dimiliki seseorang yang berdampak pada modal ekonominya.

Menanggapi gejala ini, penganut teori konflik menyatakan bahwa masyarakat sebenarnya hanyalah arena atau tempat terjadinya "pertarungan sosial" (Sadovnik, et. al., 2016). Masyarakat adalah tempat individu dan kelompok yang berbeda saling bersaing mendapatkan sumber daya langka dan bernilai. Pertarungan inipun terjadi di sekolah. Dalam masyarakat modern, status pendidikan adalah "nilai" yang harus diperjuangkan. Pada akhirnya, sekolah menjadi sebuah komoditas mahal.

Para pengikut teori konflik menyatakan bahwa pada dasarnya kelompok-kelompok sosial di masyarakat memiliki kepentingan yang berbeda. Meskipun kepentingan ini dikelola dengan baik dalam masyarakat modern, sebagian orang tetap lebih diuntungkan daripada lainnya. Sebagai sebuah arena pertarungan, sekolah memiliki fungsi politis: mempertahankan ideologi penguasa. Sekolah berfungsi mempertahankan dominasi kekuasaan. Pendidikan kapitalistik memfungsikan sekolah sebagai sarana mempertahankan posisi kelas atas agar posisi mereka tidak tergantikan individu kelas bawah yang berhasil memperbaiki posisinya. Dalam hal ini, fungsi sekolah sebagai sarana melakukan mobilitas sosial dihambat kaum kapitalis.

\section{Sekolah sebagai "Arena" Kekerasan Simbolik}

Ketika sekolah menjadi arena pertarungan kepentingan antaraktor, sekolah kemudian menjadi sarana pertarungan kekuasaan. Gejala ini menarik perhatian Bourdieu yang bertolak dari pandangan teori konflik. Kehidupan sosial masyarakat diwarnai ketimpangan sosial. Pada kondisi sosial ini, sekolah seharusanya berperan mengeliminasi ketimpangan tersebut. Akan tetapi dalam kenyataannya sekolah justru meningkatkan ketimpangan sosial tersebut.

Permasalahan ini dapat dianalisis dengan tesis Bourdieu. Bourdieu berhasil mengungkap sisi epistemologis di balik "budaya yang berkembang di sekolah" serta "bagaimana posisi kelas bawah di sekolah". secara sederhana ia menyatakan bahwa sekolah didominasi individu dari kelas atas sebagai kelompok dominan.

Menurut Bourdieu (1973), perbedaan kelas sosial berkaitan erat dengan masalah modal yang dimiliki individu. Setidaknya, ia mengidentifikasi empat bentuk modal yang mampu membedakan posisi sosial individu satu dengan lainnya. Keempat modal tersebut adalah: modal budaya, modal ekonomi, modal sosial, dan modal simbolik. Modal ekonomi adalah segala sesuatu yang dapat dikonversikan menjadi uang. Ini berkaitan dengan perbedaan kemampuan ekonomi individu atau kemampuan dalam memiliki materi. Modal budaya berupa penguasaan informasi dalam segala bentuknya. Ini adalah pengetahuan, kode-kode budaya, serta etika yang berperan dalam penentuan dan reproduksi kedudukan-kedudukan sosial yang dimiliki individu. Modal sosial adalah semua sumber daya yang didasarkan pada hubungan sosial dan keanggotaan dalam suatu kelompok. Candland (2000) menyebutkan bahwa kepercayaan seseorang dapat menjadi sebuah modal sosial bagi individu tersebut. Modal simbolik yaitu status yang diberikan kepada setiap modal tersebut apabila telah mendapat pengakuan dan penerimaan publik. Modal simbolik melekat dalam berbagai status yang dimiliki individu.

Perbedaan kemampuan memilliki (atau mendapatkan) modal tersebut merupakan kendala bagi sebagian besar individu untuk memasuki posisi kelas tertentu. Setiap kelas sosial memiliki modal berbeda. Perbedaan kepemilikan modal ini kemudian berimplikasi pada habitus yang dimiliki individu yang menempati kelas tersebut. Habitus merupakan serangkaian nilai, norma, gaya hidup, atau kecenderungan yang menuntun perilaku seseorang melalui sosialisasi (Wacquant, 2013). Habitus dimiliki dan mencerminkan posisi atau kelas sosial tertentu bagi pemiliknya karena kepemilikan modal mereka berbeda (Haralambos \& Holborn, 2007). Dengan kata lain, modal yang dimiliki siswa miskin berbeda dengan modal yang dimiliki siswa kaya. Akibatnya, habitus yang dimiliki keduanya juga berbeda.

Kelas atas (atau kelas dominan) adalah kelas yang memiliki banyak modal. Dengan menggunakan kekuatan ini, kelas dominan berusaha agar posisinya tidak akan pernah tergantikan individu lainnya. Dominasi diwujudkan di sekolah. Sebagaimana dijelaskan sebelumnya, bagi Bourdieu sekolah tidak lain hanyalah sebuah arena atau tempat pertarungan. Sekolah hanya menjalankan proses reproduksi budaya (cultural reproduction), yaitu sebuah mekanisme untuk membantu mengabadikan ketidaksetaraan ekonomi antargenerasi (Giddens, 2006). Sekolah sebenarnya gagal mewujudkan kesetaran sosial.

Cara yang ditempuh kelompok dominan mempertahankan posisinya adalah melalui apa yang dinamakan sosialisasi habitus. Dalam kenyataannya, meskipun habitus setiap kelas adalah berbeda, dan habitus bergantung pada kepemilikan modal, akan tetapi habitus dapat ditularkan dari kelas sosial yang satu ke kelas sosial lain. Penularan ini dapat dilakukan melalui sosialisasi yang berlangsung secara implisit, sehingga kelompok yang "meniru” habitus 
sosial tersebut melakukan imitasi tanpa menyadarinya (Bourdieu, 1984).

Sosialisasi habitus dilakukan menggunakan instrumen bahasa untuk memengaruhi pengetahuan individu (Bourdieu \& Passeron, 1977). Inilah yang kemudian dinamakan proses kekerasan simbolik. Kekerasan simbolik salah satunya terjadi dalam praktik pendidikan di sekolah. Kekerasan simbolik dapat terjadi ketika ketika seorang guru menyatakan posisi dirinya lebih tinggi. Akibatnya siswa harus mematuhinya.

Menurut Bourdieu (Bourdieu \& Passeron, 1977), dalam praktiknya sekolah menjalankan fungsi reproduksi sosial dan sekolah lebih banyak melayani kebutuhan kelas atas atau kelas dominan. Kelas atas memosisikan dirinya sebagai kelas dominan, sementara kelas bawah diposisikan sebagai objek dominasi. Ketika kelas dominan mendapat "posisi terhormat" di sekolah, maka mereka pun semakin leluasan menyosialisasikan habitusnya. Mereka tidak hanya menyosialisasikan habitus, akan tetapi mereka juga memaksakan habitusnya pada kelompok lain.

Studi yang dilakukan Martono (2012) menunjukkan bagaimana materi pelajaran di sekolah sebagian besar hanya menyajikan habitus-habitus kelas dominan. Studi yang dilakukan dengan menganalisis isi BSE (buku sekolah elektronik) SD menunjukkan bahwa sebagian besar kalimat dan gambar yang dimuat dalam BSE memuat habitus kelas dominan (kelas atas). Ada beberapa mekanisme yang digunakan untuk menyosialisasikan habitus kelas atas melalui BSE. Pertama, menceritakan kebiasaan-kebiasan kelas atas, misalnya: bertamasya, merayakan ulang tahun, menonton televisi, membaca koran, bermain PS di rumah, mengikuti les piano, serta mencuci mobil. Kedua, memperlihatkan atau menceritakan benda-benda yang biasa dimiliki kelas atas sebagai contoh, misalnya: televisi, kulkas, kitchen set, wastafel, mobil-mobilan (tamiya), mobil (mencuci mobil), garasi, vacuum cleaner, akuarium, serta rumah mewah. Ketiga, menggambarkan profil atau ciri-ciri kelas atas, misalnya: bekerja di kantor, memakai dasi, berangkat bekerja dengan naik mobil, bekerja membawa koper dan bersepatu. Habitus-habitus tersebut disajikan dalam materi pengantar (apersepsi), cerita, dan soal latihan.

Di sisi lain, habitus kelas bawah yang digambarkan dalam BSE jumlahnya sangat sedikit. Habitus kelas bawah digambarkan dalam BSE melalui mekanisme: pertama, menggambarkan karakter kelas bawah, misalnya: bekerja di sawah, bekerja sebagai petani, nelayan, penggembala, tukang batu, serta pemulung. Kedua, menceritakan aktivitas yang biasa dilakukan individu dari kelas bawah, misalnya: membajak sawah, menggembala, mencangkul, menanam padi, dan membantu orang tua mencari nafkah.

Ketika habitus kelas atas mendominasi praktik pendidikan, tentu saja secara tidak langsung telah mengeliminasi keberadaan kelas bawah di sekolah.
Keberadaan mereka seolah dianggap tidak ada, pasalnya habitus mereka jarang dan hampir tidak disosialisasikan di sekolah. Parahnya, siswa miskin juga menganggap hal ini sebagai sesuatu yang wajar. Mereka tidak menyadari bahwa budaya dan kebiasaannya sering menjadi bahan cemoohan di sekolah. Mereka juga mengamini bahwa budaya orang kaya adalah budaya yang sangat ideal, budaya yang baik, sehingga mereka pun ingin meniru kebiasaan teman-temannya tersebut (Martono, 2012).

Deskripsi secara jelas menunjukkan bahwa menyatukan siswa kelas atas dan kelas bawah di satu sekolah tidak menyelesaikan masalah secara sosiologis. Siswa miskin memang "bersyukur" dapat bersekolah di sekolah yang selama ini hanya dapat dimasuki orangorang kaya. Namun sebenarnya keberadaan mereka di sekolah dianggap tidak ada. Sekolah kemungkinan tidak mengakomodasi latar sosial siswa miskin sehingga guru menggunakan standar tunggal, yaitu standar kelas dominan (siswa kelas atas). Akibatnya, siswa miskin dipaksa mengikuti cara kerja dan cara belajar siswa kelas atas, padahal keduanya memiliki kemampuan yang sangat berbeda.

Uraian ini menunjukkan bahwa Bourdieu telah berhasil menegaskan bahwa kekuasaan bukanlah dominasi negara semata. Namun dalam praktiknya, peran kelompok kelas atas lebih dominan dan mereka berhasil mengatur segala hal yang terjadi di sekolah, termasuk membatasi apa saja yang dianggap layak atau tidak layak untuk dimasukkan dan dipelajari di sekolah.

\section{METODE}

Penelitian ini menggunakan metode kualitatif. Ada beberapa alasan penggunaan metode kualitatif dalam penelitian ini. Pertama, peneliti ingin menggambarkan bagaimana siswa memahami situasi sosial di sekolah ketika sekolah terdapat banyak siswa dari latar sosial yang berbeda, dan mereka masing-masing membawa habitus yang berbeda. Kedua, penelitian ini juga menggambarkan berbagai upaya yang dilakukan siswa kelas bawah (siswa miskin) menghadapi dominasi habitus siswa kaya di sekolah. Ketiga, penelitian ini menggambarkan proses interaksi sosial siswa miskin dan siswa kaya di sekolah.

Subjek penelitian ini adalah siswa miskin yang bersekolah di sekolah favorit dengan mayoritas siswa kaya, yaitu dua SMA favorit di Kota Cilacap Jawa Tengah. Untuk mengumpulkan data, penelitian ini menggunakan metode wawancara, observasi, pengumpulan data sekunder.

Untuk menganalisis data, studi ini menggunakan metodeanalisiskomparatifkonstan(constantcomparative). Alasan dipilihnya metode analisis ini adalah peneliti ingin melakukan komparasi mengenai pengalaman-pengalaman yang dialami siswa miskin di sekolah favorit. Pengalaman ini juga mencakup pengalaman ketika mereka berinteraksi 
dengan siswa kaya yang merupakan kelompok mayoritas di sekolahnya.

\section{HASIL DAN PEMBAHASAN}

\section{Bersekolah di sekolah favorit}

Bersekolah di sekolah favorit, bagi golongan kelas menengah ke bawah bukanlah sebuah mimpi yang mudah diwujudkan. Sekolah favorit di banyak tempat adalah sekolah mahal. Untuk dapat masuk ke sekolah tersebut, modal kecerdasan otak tidaklah cukup sebagai modal utama. Namun, siswa miskin harus memutar otak lebih keras untuk mencari sumber dana agar berhasil diterima di sekolah favorit. Ini berbeda dengan siswa kaya yang dapat bebas memilih bersekolah di manapun.

Ada banyak cerita mengenai awal mula siswasiswa miskin kemudian berhasil masuk ke "sekolah milik orang kaya". Di beberapa media pun banyak cerita yang mengekspos perjuangan mereka, namun sayangnya, hanya sekian persen saja yang dapat melanjutkan mimpimimpi tersebut. Sebagian besar siswa kelas bawah gagal mendapatkan fasilitas pendidikan berkualitas, bukan sekedar bersekolah. Berikut beberapa cerita dari informan mengenai keberhasilannya "bersaing" dengan siswa kelas atas untuk masuk ke sekolah favorit.

ADT.ADT adalah anak kelima dari lima bersaudara. Kakaknya sudah menikah kecuali kakak keempatnya. Ayahnya berusia 60 an tahun, bekerja sebagai buruh petani kelapa, dan ibunya bekerja sebagai buruh tani membantu ayahnya. Jika melihat aktivitas kedua orang tuanya, ADT sulit mewujudkan mimpinya bersekolah di sekolah favorit.

Awalnya, sang kakak menyarankan ADT untuk masuk ke MAN (Madrasah Aliyah Negeri) yang dekat dengan tempat tinggalnya. Pertimbangan biaya menjadi alasan kakaknya menyarankan hal tersebut. Di sisi lain, ADT agak pesimis dapat mendaftar ke sekolah favorit karena nilainya pas-pasan. Faktor biaya juga menjadi pertimbangan berikutnya. Dari aspek biaya sekolah, MAN relatif lebih murah daripada SMA negeri di kota yang sama.

Meskipun pesimis, namun pada akhirnya ADT memutuskan mendaftar ke salah satu SMA favorit di Cilacap. Pada saat pengumuman hasil seleksi, ADT dinyatakan diterima, namun ia berencana mengurungkan niatnya untuk bersekolah di SMA tersebut karena pertimbangan biaya. Pada saat yang hampir bersamaan, ia bertemu dengan salah satu guru di SMA tersebut, yaitu JM. JM menyatakan akan membantu masalah biaya sekolah untuk ADT jika ia diterima di SMA tersebut.

ADT tinggal di masjid sekolah bersama keempat temannya karena rumahnya cukup jauh dari sekolah. Ia tinggal di masjid sekolah secara gratis. Iapun dibebaskan dari kewajiban membayar biaya sekolah.

RIK. RIK adalah salah satu siswa berprestasi SMA- nya. Kakaknya kini sedang menempuh pendidikan di salah satu perguruan tinggi negeri di Semarang. Ia tinggal di Kecamatan Karangreja, sekitar 60 km dari Kota Cilacap bersama dengan ayahnya yang bekerja sebagai penjahit merangkap petani. Ibu RIK sudah meninggal dunia karena sakit. Selama menempuh studi di Cilacap, RIK tinggal di masjid sekolah bersama dengan ADT. Awalnya RIK pun ragu dapat bersekolah di salah satu sekolah favorit di Cilacap.

Ketika SMP, RIK memang mendambakan dapat bersekolah di SMA tersebut karena berharap mendapatkan beasiswa dari bupati Cilacap. Namun sayangnya, ketika RIK lulus SMP, program beasiswa tersebut sudah tidak ada lagi. Ia pun mengurungkan niatnya bersekolah di Cilacap karena ketiadaan biaya. RIK berniat mendaftar di SMA yang dekat dengan rumahnya untuk menghemat biaya.

Namun, pada saat bersamaan, ia mendapat informasi beasiswa untuk masuk ke SMA favorit di Cilacap. Ia pun mendapat beasiswa atas bantuan dari salah satu guru di SMA tersebut. RIK mendapatkan pembebasan biaya SPP dan keringanan biaya pembangunan gedung, sehingga ia hanya membayar Rp 2.400.000 dari biaya yang seharusnya yaitu $\operatorname{Rp} 5.000 .000$.

Selama belajar di SMA tersebut, RIK berhasil menunjukkan prestasinya. Ia menjuarai beberapa kompetisi sampai tingkat provinsi dan nasional mewakili sekolahnya.

KRS. KRS adalah anak pertama dari tiga bersaudara. Orang tuanya sudah bercerai, dan ia tinggal bersama ibu dan neneknya. Ibunya berjualan makanan kecil (snack) atau jajanan pasar yang dititipkan di sekolah-sekolah di sekitar rumahnya, sedangkan neneknya adalah seorang buruh. Sementara KRS juga membantu ibunya berjualan makanan kecil di sekolah. Jadi, sambil bersekolah, KRS juga menawarkan dagangannya ke teman-temannya di sekolah.

Sama dengan RIK, KRS juga sudah mendambakan bersekolah di SMA favorit di Cilacap. Rumah KRS tidak jauh dari sekolah, sehingga setiap hari ia berangkat dari rumah ke sekolah yang berjarak kurang lebih enam kilometer.

Setelah lulus SMP, KRS langsung mendaftar ke SMA favorit di Cilacap dan dinyatakan diterima. Pada awalnya ia juga ragu bersekolah di SMA tersebut karena ketiadaan biaya. Akan tetapi, ia kemudian berhasil mendapatkan pembebasan biaya sekolah bulanan dan keringanan biaya pembangunan.

FIN. Di Cilacap FIN tinggal bersama bibi dan sepupunya, sedangkan orang tuanya tinggal di Karawang, Jawa Barat. Orang tua FIN bekerja sebagai buruh di Karawang, sementara bibinya berjualan snack buatan sendiri. Paman FIN bekerja sebagai nelayan dan pulang dua minggu sampai satu bulan sekali. 
FIN diterima di salah satu SMA favorit di Cilacap dengan berbekal nilai yang cukup memuaskan meskipun secara ekonomi cukup berat. Selama bersekolah, FIN mendapatkan keringanan SPP dan pengurangan biaya pembangunan gedung. Setelah dikurangi keringanan, FIN membayar SPP sebesar Rp 100.000/bulan dan biaya pembangunan sebesar Rp 3.750.000 yang dapat diangsur selama tiga tahun.

Perjuangan belum selesai, ternyata FIN tidak hanya mengeluarkan biaya untuk itu saja. Bersekolah ternyata tidak sekedar membayar biaya SPP dan pembangunan gedung saja, akan tetapi FIN masih dibebani biaya lain: biaya pembuatan jas untuk praktikum di laboratorium, serta seragam ekstrakurikuler jika ia mengikuti ekstrakurikuler tertentu. Menurut pengakuan FIN, semuanya bersifat wajib dan sulit untuk mewarisi seragam milik kakak kelas karena hampir setiap tahun warna seragam praktikum berbeda.

FKR. FKR adalah anak pertama dari dua bersaudara. Ia tinggal bersama ibu dan ayah tirinya karena ibunya telah bercerai dan ayah kandungnya sudah menikah lagi. Ibunya bekerja dengan menerima pesanan kue buatan sendiri, sementara ayah tirinya bekerja sebagai tenaga kontrak di perusahaan properti.

Sama seperti FIN, FKR juga langsung diterima di SMA favorit dengan berbekal nilai yang mencukupi. Namun FKR berbeda dengan FIN karena FKR tidak mendapatkan keringanan SPP meskipun ia berasal dari keluarga tidak mampu. FKR mengaku telah mengajukan keringan pembayaran SPP namun pihak sekolah belum memberinya keringanan. Akibatnya hampir setiap bulan FKR harus terlambat membayar SPP.

Itulah beberapa profil singkat siswa yang menjadi informan dalam penelitian ini. Penuturan kelimanya menunjukkan beberapa kesamaan. Pertama, mereka masuk ke SMA favorit dengan bermodal nilai masuk yang mencukupi. Kedua, mereka memiliki modal ekonomi yang pas-pasan bahkan kurang sehingga mereka harus mengajukan keringanan biaya bulanan dan biaya pembangunan gedung. Ketiga, orang tua mereka tidak memiliki penghasilan tetap sehingga sulit untuk memenuhi semua kebutuhan sekolah secara maksimal.

Bersekolah di sekolah favorit bukanlah sebuah perjuangan yang mudah. Mereka harus siap hidup sederhana dan prihatin. Dua informan (ADT dan RIK) memilih tinggal di masjid sekolah agar tidak perlu membayar kos. Mereka pun berupaya mengajukan keringanan SPP agar dapat bertahan hidup selama studi.

Informasi yang diperoleh dari informan tersebut menunjukkan bahwa sekolah favorit masih memiliki image sebagai sekolah mahal. Ini berakibat siswa miskin merasa was-was tatkala memberanikan diri mendaftar di sekolah favorit. Kecemasan bahwa dirinya akan kesulitan membayar biaya sekolah yang relatif sangat mahal terus menghantui pikiran mereka. Bahkan, siswa yang relatif cerdas pun masih berpikir dua kali untuk mendaftar di sekolah favorit.

Meskipun ada dana BOS dari pemerintah pusat, namun nyatanya bantuan tersebut tidak membantu menyelesaikan masalah yang dihadapi siswa miskin. Sebut saja kasus FIN yang harus membayar Rp 3.750.000 yang dapat diangsur selama tiga tahun. Nominal ini belum termasuk komponen lainnya, seperti: seragam praktikum dan seragam ekstrakurikuler.

FIN menjelaskan:

"... ada banyak iuran... ya iuran buat beli baju... waktu itu harus beli jas lab, terus kalau ikut organisasi kan juga butuh jas blazer. Jas lab harganya 85 ribu, kalau blazer OSIS ada yang harganya 105 ribu sama yang 125 ribu..." (FIN, 10/2/2018)

Masalah seragam masih menjadi momok bagi siswa miskin. Pembelian seragam di luar seragam sekolah adalah di luar subsidi melalui dana BOS. Ini artinya mereka harus membayar sendiri di luar biaya SPP. FIN menjelaskan bahwa ketika ia mengikuti sebuah organisasi intrakurikuler di sekolah, berarti ia harus menyiapkan rupiah lebih banyak. Rupiah itu digunakan untuk membeli seragam organisasi intrasekolah; OSIS memiliki seragam sendiri, begitu pula Pramuka dan Rohis. Biaya di luar SPP memang sering kali memberatkan siswa kurang mampu. Biaya ini pun belum termasuk pembelian LKS (Lembar Kerja Siswa) sebagai pelengkap buku pelajaran yang bersifat wajib beli.

\section{Menghadapi teman "beda habitus"}

Berinteraksi dengan teman dari kelas sosial berbeda adalah salah satu risiko yang harus dihadapi siswa kurang mampu ketika memutuskan bersekolah di sekolah favorit. Sekolah mahal menyebabkan sekolah favorit didominasi siswa kaya. Dampaknya adalah siswa miskin menjadi minoritas. Sebagai minoritas, mereka pun secara tidak langsung dipaksa menyesuaikan diri dengan budaya yang dianut kelompok mayoritas.

Ada beragam pilihan yang harus diambil siswa miskin ketika beradaptasi di lingkungan sekolah tersebut. Mereka pun bebas menentukan sikap: antara hanyut dalam gaya hidup yang berbeda dengan gaya hidup kesehariannya, atau memilih menjaga jarak agar tetap menjadi diri sendiri dan mempertahankan budayanya. Bagi siswa miskin, hanyut dan terlibat dalam budaya kelas atas bukanlah tanpa konsekuensi.

Ada banyak sikap dan perasaan siswa miskin ketika mereka harus "berhadapan" dengan teman-temannya dari kelas atas.

FIN misalnya, ia merasa tidak dekat dengan temanteman sekelasnya yang mayoritas siswa kaya. Ia hanya memaknainya sebagai teman biasa atau teman main saja, 
dan FIN mengaku tidak pernah memosisikan temannya tersebut sebagai teman curhat. Satu kata yang berulang kali ia ucapkan adalah "minder"; minder ketika bergaul dengan teman-temannya di kelas. FIN menyatakan:

"Baik, cuman mmm...mungkin ... semua temen-temen itu orang berpunya ya... jadi saya agak minder sedikit.. Ya mungkin rasa malu juga ada, cuman ya gitu.. hehehe... Cuma waktu lihat ke sini-ke sininya temen-temen banyak yang dari anak berpunya...." (FIN, 10/2/2018)

Dalam wawancara dengan FIN, ia tidak secara jelas menjelaskan mengapa ia merasa minder. Ia hanya mengatakan "ya minder karena saya beda dengan mereka..." (FIN, 10/2/2018).

FIN berangkat sekolah dengan mengendarai sepeda sejauh lima kilometer dari rumahnya. Kadang kala ia baru tiba di rumah setelah maghrib karena ada kegiatan di sekolah. Sepulang sekolah ia membantu bibinya di rumah sehingga kadang tidak sempat belajar.

FIN memilih bersikap "menolak" bergabung dalam aktivitas teman sekolahnya. FIN menuturkan:

“... pernah diajak makan-makan bareng di mall tapi saya nolak.... Pernah juga diajak nonton bioskop... tapi ga mau..." (FIN, 10/2/2018)

Sementara, hingga memasuk kelas XI, FIN masih menjaga jarak dengan teman-temannya. Ini terlihat dari penolakannya ketika diajak bermain temannya. Ketiadaan biaya menyebabkan FIN memilih lebih sering di rumah daripada bermain dengan temannya.

Informan lain yaitu RIK, mengaku memilih tidak bergabung dengan teman-teman sekelasnya. Selama bersekolah di SMA, RIK hanya memiliki satu teman akrab karena sama-sama datang dari desa. RIK merasa tidak cocok dengan teman-teman sekelasnya. Bahkan, pada awal masa sekolahnya, RIK sempat meminta pindah sekolah karena merasa tidak cocok dengan lingkungan sosial di sekolah tersebut yang mayoritas "high class".

RIK menuturkan:

“...saya kan juga bukan orang kota, saya orang desa, nah itu saya nggak punya laptop dan macem-macem, nah itu saya minder ......." (RIK, 26/1/2018)

“.... Awal sekolah di sini saya memang minder. Sampai kalau nggak ditanya temen atau nggak disuruh ngomong sama guru, saya diem..." (RIK, 26/1/2018)

"Minder" adalah perasaan yang dialami RIK dan FIN ketika masuk ke sekolahnya. Suasana yang benarbenar baru dengan teman-teman yang berbeda kelas sosial membuat keduanya tidak percaya diri. Kepercayaan diri RIK tumbuh setelah ia mengikuti berbagai perlombaan dan berhasil mendapatkan juara sampai tingkat nasional. Menjadi juara adalah modal budaya yang menjadi kebanggaan diri RIK.
Meskipun lebih percaya diri, akan tetapi RIK memilih tidak terlalu dekat dengan teman sekelasnya yang menurutnya "high class". Ia merasa tidak memahami isi pembicaraan teman-temannya.

“... Masalahnya kalau saya bergaul dengan orangorang kota sini, orang Cilacap itu kalau kita bicara itu kadang nggak nyambung ... Misalnya kalau orang-orang desa itu kan bicaranya masalah-masalah sederhana. ... Mungkin ya, masalah main di rumah kayak apa, terus kalau olah raga, anak desa main bola ... tapi kalau anak kota itu membicarakannya hal yang lain kayak film bioskop lah, apalah itu, jadi kadang kalau saya mau bergaul kurang cocok dengan pembicaraan mereka, nggak nyambung kalau bicara..."(RIK, 26/1/2018)

Budaya yang berbeda menyebabkan RIK sulit bergabung dengan temannya. Ia sering tidak memahami apa yang sedang diperbincangkan temannya. Kutipan ini mengisyaratkan bahwa perbedaan budaya antara siswa miskin dan siswa kaya berpotensi menghambat proses interaksi di antara keduanya.

Minder juga dirasakan ADT. Berteman dengan teman kelas atas, bagi ADT memang memerlukan biaya yang tidak sedikit untuk ukurannya. Sering kali ia juga harus menolak ajakan temannya untuk sekedar nongkrong di café, ataupun nonton film di bioskop. ADT menuturkan:

“.... Saya nggak pernah nonton ke bioskop... Saya mikir-mikir uangnya lebih enak buat makan daripada buat nonton .... Saya memberikan alasan yang sejujur-jujurnya...” (ADT, 26/2/2018)

Nonton bioskop, nongkrong di café adalah habitus kelas atas. Ketika mereka mengajak temannya yang berasal dari kelas bawah, sebenarnya di sini ada sebuah proses "mengajak teman untuk mengikuti habitusnya". Ajakan ini menjadi sebuah hal yang sulit diterima karena habitus-habitus tersebut memerlukan modal ekonomi (memerluka uang karena harus membayar), sementara dalam kasus FIN, RIK, ADT, mereka hampir tidak memiliki modal ekonomi tersebut.

Mereka merasa minder karena tidak mampu sehingga tidak dapat mengikuti habitus teman-temannya. Dalam hal kepemilikan perlengkapan sekolah pun mereka "berbeda". Salah satu informan berinisial MNA mengatakan bahwa ia terpaksa harus belajar dengan temannya karena ia tidak memiliki laptop. Berikut kutipan wawancara dengan MNA:

“ ... Bikin minder ya.. paling irinya cuma karena temen-temen punya laptop, saya nggak punya. ... Ya rasanya kaya gitu bu.. nggak bisa dijelasin. ... Biasanya ya.. misal kalau ada tugas yang butuh komputer ya harus ke warnet ...." (MNA, 26/2/2018) 
Tidak memiliki laptop adalah penyebab MNA merasa minder. Kendala serupa juga dialami FIN. Sementara, RIK pada awalnya juga minder karena tidak memiliki laptop, namun pada akhirnya ia berhasil membeli laptop berkat keberhasilannya menjuarai kompetisi tingkat nasional. Hadiah kompetisi tersebut digunakan untuk membeli laptop.

Ketersediaan perlengkapan sekolah sering kali menjadi hambatan siswa miskin untuk mengejar ketertinggalannya dengan siswa kaya. Sementara, beberapa sekolah favorit sering menyaratkan kepemilikan perlengkapan tersebut dalam rangka penyusunan tugas sekolah. Bagi siswa kaya hal ini bukanlah masalah besar, akan tetapi bagi siswa miskin ini adalah masalah serius. Untuk itu, usaha atau perjuangan siswa miskin untuk meraih prestasi di sekolah favorit memang tidak mudah. Mereka harus berkompetisi dengan siswa kaya dengan "modal" yang berbeda, namun mereka harus mencapai target yang sama.

Sekolah adalah arena pertemuan berbagai habitus. Namun dalam praktiknya sebagian sekolah justru dikuasai kelompok tertentu yang mendominsi habitus yang berlaku di sekolah tesebut. Sekolah favorit yang diposisikan masyarakat sebagai sekolah terbaik dalam kenyataannya dikuasai kelompok dominan, yaitu kelas atas. Bourdieu (1973) menyatakan bahwa sekolah hanya mengajarkan habitus kelas dominan. Dengan kata lain, habitus yang diterapkan di sekolah-sekolah (terutama sekolah favorit) adalah habitus kelas atas. Hasilnya adalah ketika ada siswa kelas bawah mencoba peruntungannya masuk ke sekolah favorit, secara tidak langsung mereka juga harus (baca: dipaksa) menyesuaikan habitusnya dengan habitus kelas atas.

Keduanya memiliki modal berbeda. namun dengan modal berbeda, mereka dikenai aturan atau standar yang sama. Situasi ini tentu lebih menguntungkan siswa yang memiliki modal lebih tinggi.

Sekolah negeri pada dasarnya merupakan sekolah inklusi yang menyatukan siswa dari berbagai latar belakang sosial. Ini bertujuan memberikan kesempatan yang sama pada semua siswa untuk mengakses pendidikan dengan kualitas yang sama. Namun di sisi lain, ini menjadi kesempatan yang "merugikan". Siswa miskin dapat kehilangan eksistensinya karena mereka dipaksa melebur dengan siswa kaya, dan secara otomatis habitus kelas bawah pun akan hilang (dianggap tidak ada). Kalaupun eksistensi habitus kelas bawah ada, posisinya tetap tidak menguntungkan pemilik habitus tersebut.

Inilah efek dominasi kelas di sekolah yang digagas Bourdieu. Habitus siswa miskin sering kali dianggap sebagai habitus kuno, tidak gaul, kotor, jauh dari kemajuan atau ketinggal jaman, bahkan dianggap kampungan. Sementara, habitus kelas atas selalu diposisikan sebagai habitus yang baik, layak menjadi contoh, habitus modern dan maju sehingga harus diikuti dan dipertahankan.
Di sisi lain, keberhasilan segelintir siswa kelas bawah dalam memenangkan pertarungan dalam pendidikan di sekolah sering kali diklaim sebagai motivasi bagi masyarakat kelas bawah. Namun sebenarnya peluang keberhasilan tersebut hanya sepersekian persen dari keseluruhan siswa kelas bawah yang mencoba peruntungannya di sekolah-sekolah favorit.

Dalam salah satu tesisnya, Bourdieu menjelaskan bahwa kelas atas akan berupaya menghambat kelas bawah untuk menaikkan statusnya. Kelas atas menggunakan pendidikan di sekolah sebagai mekanisme mempertahankan statusnya. Ketika individu (siswa) kelas bawah pada akhirnya dapat masuk ke sekolah yang sama dengan kelas atas, maka kelas atas berupaya membuat siswa kelas bawah "tidak nyaman" berada di sekolah.

Hasil wawancara dengan RIK sebelumnya menunjukkan bagaimana ketika ia berada di sekolah sering kali tidak dapat menangkap topik pembicaraan temantemannya yang mayoritas berasal dari kelas atas. RIK merasa tidak nyambung atau tidak mengerti apa yang sedang diperbincangkan teman-temannya. Ini disebabkan apa yang dibicarakan teman RIK bukanlah menjadi budaya keseharian RIK (baca: bukan habitusnya). Ketika RIK mencoba bergabung dalam obrolan tersebut, maka secara tidak langsung sebenarnya RIK dipaksa mengerti kehidupan keseharian teman-temannya mayoritas adalah kelas atas. Sementara, RIK dan hampir semua siswa kelas bawah tidak memiliki kesempatan untuk "menceritakan" bagaimana kehidupan keseharian mereka. Habitus mereka pun dianggap tidak ada atau bahkan hilang.

Selain itu, dalam kasus yang dialami MNA ia berhasil masuk ke sekolah favorit. Namun, ia tidak dapat mengimbangi kemampuan yang dimiliki temantemannya, yaitu ia tidak mampu memiliki sebuah laptop yang menjadi "syarat" utama ketika mengerjakan tugas sekolah. Ia pun terpaksa mengerjakan di warnet ketika harus mengerjakan tugas yang pengerjaannya memerlukan internet atau laptop. Inilah modal ekonomi yang tidak dimiliki MNA yang membedakannya dengan temannya di sekolah.

Selain itu, beberapa informan terpaksa tidak mengikuti ajakan temannya untuk melakukan aktivitas bersama, misalnya nongkrong ataupun nonton bioskop. Mereka mengaku menolak ajakan temannya karena tidak memiliki uang cukup.

FIN harus membeli seragam ketika mengikuti kegiatan intrakurikuler dan ekstrkurikuler. Memang ia mendapat keringanan biaya sekolah, akan tetapi ia tetap diwajibkan membeli seragam praktikum, seragam organisasi sekolah (OSIS, Pramuka, Rohis, dan seragam ekstrakurikuler lainnya), membeli LKS dan perlengkapan lainnya di luar SPP. FIN juga masih dibebani biaya pembangunan sekolah yang harus diangsur selama tiga tahun. 
Ketidakmampuan ini menjadi penyebab munculnya rasa minder ketika mereka berinteraksi dengan temannya. Rasa minder ini sebenarnya menunjukkan bahwa siswa kelas bawah gagal menyesuaikan diri dengan habitus kelas atas. Sementara, beberapa informan memilih menolak dengan sengaja karena mereka merasa tidak cocok dengan habitus kelas bawah. RIK menyatakan ingin fokus belajar sehingga ia membatasi waktu bermain dengan temantemannya.

Inilah mekanisme kelas atas untuk menghambat kemajuan kelas bawah di sekolah. Kelas bawah memang diberi kesempatan masuk ke sekolah favorit namun di sekolah mereka dibuat tidak nyaman. Melalui kekerasan simbolik ini, kelas atas tetap dapat mempertahankan posisinya.

Temuan penelitian ini memberikan pembaruan dalam teori Bourdieu bahwa tesis Bourdieu ternyata tidak menggambarkan mengenai strategi bertahan siswa miskin di sekolah-sekolah publik ketika mereka harus berhadapan dengan siswa kaya sebagai mayoritas. Bagaimana kemudian ketika sekolah didominasi kelas atas. Memang habitus siswa miskin berbeda, namun meski berbeda mereka tetap harus dapat bertahan sampai mereke menyelesaikan sekolah. ada banyak usaha yang mereka lakukan: menghemat pengeluaran (memilih tinggal di masjid daripada pulang), atau menahan keinginan untuk bersenang-senang, dan memilih menggunakan uangnya untuk makan sehari-hari, membeli laptor, dan lainnya.

Berikutnya, hasil penelitian ini memberikan sumbangan pemikiran bahwa ada banyak cara yang dilakukan siswa miskin untuk menghadapi dominasi kelas atas di sekolah. temuan dalam penelitian ini misalnya: memilih diam, menolak ajakan, dan memilih ikut jika "memiliki modal" yang diperoleh dengan cara menabung.

Siswa miskin memang "dipaksa" menerima habitus siswa kaya. Akan tetapi, siswa miskin masih memiliki opsi untuk menangkal paksaan tersebut dengan cara yang mereka pilih sendiri.

\section{SIMPULAN}

Berdasarkan hasil penelitian ini, ada beberapa hal yang dapat disimpulkan. Pertama, siswa kelas bawah merasa minder ketika harus berinteraksi dengan temannya yang berasal dari kelas atas. Rasa minder ini muncul karena mereka merasa berbeda, tidak memiliki uang sebagai "modal ekonomi". Ketiadaan modal ekonomi ini menyebabkan mereka membatasi aktivitas bersama temannya, misalnya: nongkrong di café, nonton bioskop, dan lainnya.
Kedua, mereka juga menghadapi kesulitan ketika tidak memiliki perlengkapan sekolah yang lengkap seperti yang dimiliki temannya. Misalnya: beberapa informan tidak memiliki laptop sehingga menghadapi kendala ketika mengerjakan tugas sekolah yang harus memanfaatkan laptop.

Perbedaan kepemilikan ini menunjukkan bahwa sekolah sebenarnya belum sepenuhnya mengakomodasi kondisi sosial setiap siswa. Sekelompok siswa (kelas bawah) tetap menghadapi kesulitan menyesuaikan keadaan sosialnya.

\section{DAFTAR PUSTAKA}

Bourdieu, P. (1973). Cultural Reproduction and Social Reproduction, in: Knowledge, Education, and Cultural Change. London: Tovistock.

Bowles, S. \& Gintis, H. (1978). Schooling in Capitalist America. New York: Basic Books.

Candland, C.D. (20000. Faith as social capital: Religion and community development in Southern Asia. Policy Science, 33, 355-374..

Giddens, A. (2006). Sociology, 5th Edition. Cambridge: Polity Pres.

Haralambos, M. \& Holborn, M. (2007). Sociology: Themes and Perspectives. London: Harper Collins Publisher.

Hardiman, F.B. (2010). Ruang Publik: Melacak Partisipasi Demokratis dari Polis sampai Cyberspace. Yogyakarta: Kanisius.

Martono, N. (2012). Kekerasan Simbolik di Sekolah: Sebuah Ide Sosiologi Pendidikan Pierre Bourdieu. Jakarta: Raja Grafindo Persada.

Martono, N. (2014). Dunia Lebih Indah Tanpa Sekolah. Jakarta: Mitra Wacana Media.

Martono, N. (2014). Sosiologi Pendidikan Michel Foucault. Jakarta: RajaGrafindo Persada.

Sadovnik. (2016). Exploring Education: An Introduction to the Foundations of Education. New York: Routledge.

Wacquant, L. (2013). Symbolic power and groupmaking: On Pierre Bourdieu's reframing of class. Journal of classical sociology, 13, (2), 274-291. 